\title{
OVERVIEW OF THE MECHANICAL PROPERTIES OF STEEL REINFORCED GROUT SYSTEMS FOR STRUCTURAL RETROFITTING
}

\section{FRANCESCA ROSCINI ${ }^{*}$, STEFANO DE SANTIS, PIETRO MERIGGI AND GIANMARCO DE FELICE}

\author{
Roma Tre University \\ Department of Engineering \\ Via Vito Volterra 62, 00146 Rome, Italy \\ e-mail: francesca.roscini@uniroma3.it,www.romatrestrutture.eu (*corresponding author) \\ email: \{stefano.desantis, pietro.meriggi, gianmarco.defelice\}@uniroma3.it,www.romatrestrutture.eu
}

Keywords: Steel Reinforced Grout, Composite Material, Experimental Tests, Mechanical Properties

\begin{abstract}
Steel Reinforced Grout (SRG) is a mortar-based composite recently developed for structural retrofitting, which provides high tensile strength with limited increase in mass and in stiffness, and whose effectiveness relies on the good interaction between steel cords and inorganic matrices. Many companies already supply SRG systems for rehabilitation activities and the scientific community has been working intensively on experimental and numerical investigations to demonstrate their effectiveness for structural applications, which also led to the inclusion of SRG in national and international standards for product qualification and design. However, a clear view of the mechanical properties of these systems is still lacking, due to their variability, which, in turn, strongly depends upon cord layout, textile architecture, and characteristics of the matrix. This paper provides an overview of the mechanical properties of SRG composites on the basis of the tests carried out at Roma Tre University and of the other experimental evidences available in the literature. The results of tensile tests on bare textiles and SRG coupons with different inorganic matrices, and of bond tests on masonry and reinforced concrete substrates are collected and the performances of the different SRG systems are compared. The influence of the mortar matrix on crack spacing, ultimate strain and tension stiffening in tensile tests is analysed. The capacity of the steel cords to ensure a proper shear transfer through interlocking within the matrix and the effect of cord density on failure mechanisms in bond tests are also discussed.
\end{abstract}

\section{INTRODUCTION}

Steel Reinforced Grout (SRG) is a class of innovative mortar-based composites, named as Fabric Reinforced Cementitious Matrix (FRCM), developed for structural rehabilitation, as externally bonded reinforcements of existing reinforced concrete and masonry constructions. They can enhance structural capacity without alterations of geometry, mass and stiffness. Similarly to other FRCM systems, SRG may represent a valid solution to traditional techniques, such as the installation of steel tie-bars, the construction of crowning beams or the laying of 
reinforced concrete plater overlays, which may be invasive, non-reversible, more expensive and inappropriate for applications to historical buildings. Therefore, they actually are an effective strengthening system first at all for cultural heritage thanks to their high compatibility between mortar matrix and masonry substrate.

SRG specific benefits have been demonstrated by a number of investigations carried out in different application fields. More specifically, experiments showed that the use of steel as reinforcement in FRCM composites provides an improvement of mechanical properties thanks to the ductility $[1,2]$ and the high tensile strength [3] of the textile. The layout of the cords also ensures a particularly efficient interlocking with mortar matrices, improving the bond at their interface $[4,5,6,7]$. Finally, connection and anchorage systems can be effectively added to SRG overlays $[8,9,10]$, allowing their installation on various structural members $[11,12,13$, $14]$ and ensuring particularly high gains in load carrying capacity as well [17,18]. On the basis of such investigations, SRG composites are currently included in the testing [19], acceptance [20] and design [21, 22] guides.

This paper collects the most recent research studies on SRG carried out in Roma Tre University according to EAD certification procedure [23], which followed those performed within the RILEM TC-250 CSM (Composites for the Sustainable Strengthening of Masonry) [22]. The most significant mechanical characteristics are compared to discuss the effect of the following parameters: architecture of the single cord, density of the textile, characteristics of the matrix and the substrate materials (concrete, clay bricks and tuff units).

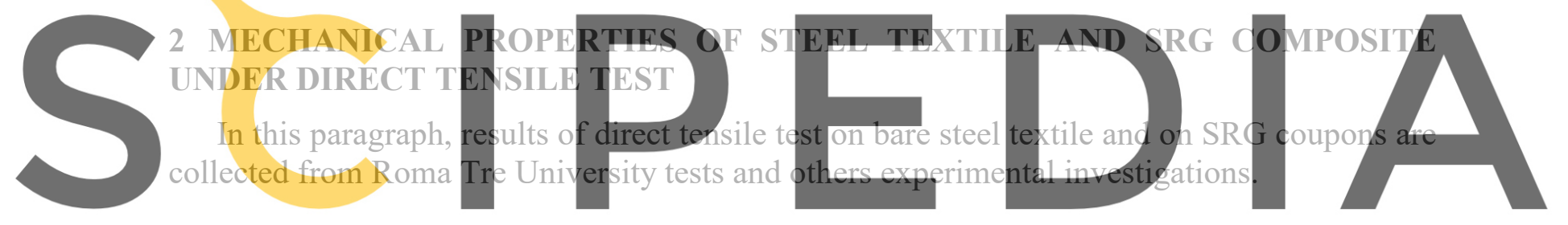

Register for free at https//www.scipedia.com to download the version without the watermark

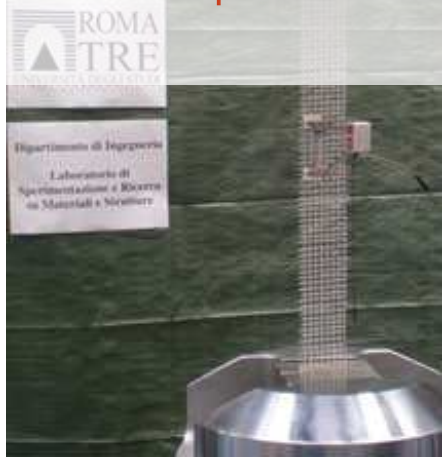

Figure 1.1: Experimental set up for tensile tests on dry textile

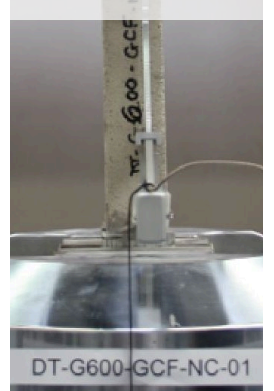

Figure 2.2: Experimental setup for tensile tests on SRG coupons

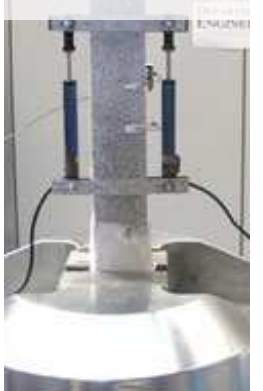

Figure 3.3: Experimental
setup for shear bond tests

\subsection{Tensile behaviour of steel textile}

Direct tensile tests (Figure 1.1) on steel textiles are carried out to obtain peak stress, corresponding strain, and Young's modulus. In particular, in this case are collected properties and results from Roma Tre University(t) [24] and RILEM TC 250-CSM ${ }^{(*)}[25,26,27]$ 
experimental studies on four typologies of steel textiles:

S1) Galvanized Steel textile, consisting in Ultra High Tensile Strength Steel (UHTSS) cords with $6.35 \mathrm{~mm}$ spacing, $0.084 \mathrm{~mm}$ design thickness and $670 \mathrm{~g} / \mathrm{m}^{2}$ surface mass density (low density). Each cord (Area $=0.538 \mathrm{~mm}^{2}$ ) is obtained by twisting 2 wires around 3 rectilinear ones, having $0.108 \mathrm{~mm}^{2}$ cross section area.

S2) Galvanized Steel textile, consisting in Ultra High Tensile Strength Steel (UHTSS) cords with $3.18 \mathrm{~mm}$ spacing, $0.169 \mathrm{~mm}$ design thickness and $1340 \mathrm{~g} / \mathrm{m}^{2}$ surface mass density (lowmedium density).

S3) Steel textile, characterized by AISI 304 stainless steel made of cords, with $3.18 \mathrm{~mm}$ spacing. Each cord (cross section area $=0.595 \mathrm{~mm}^{2}$ ) is obtained by twisting 5 wires having 0.119 $\mathrm{mm}^{2}$ cross section area; $0.188 \mathrm{~mm}$ design thickness and $1500 \mathrm{~g} / \mathrm{m}^{2}$ surface mass density.

S4) Steel textile, characterized by AISI 316 stainless steel made of ropes, obtained by twisting several small wires; ropes have a cross section area of $0.69 \mathrm{~mm}^{2}$ each and are spaced $5 m 1 n$.

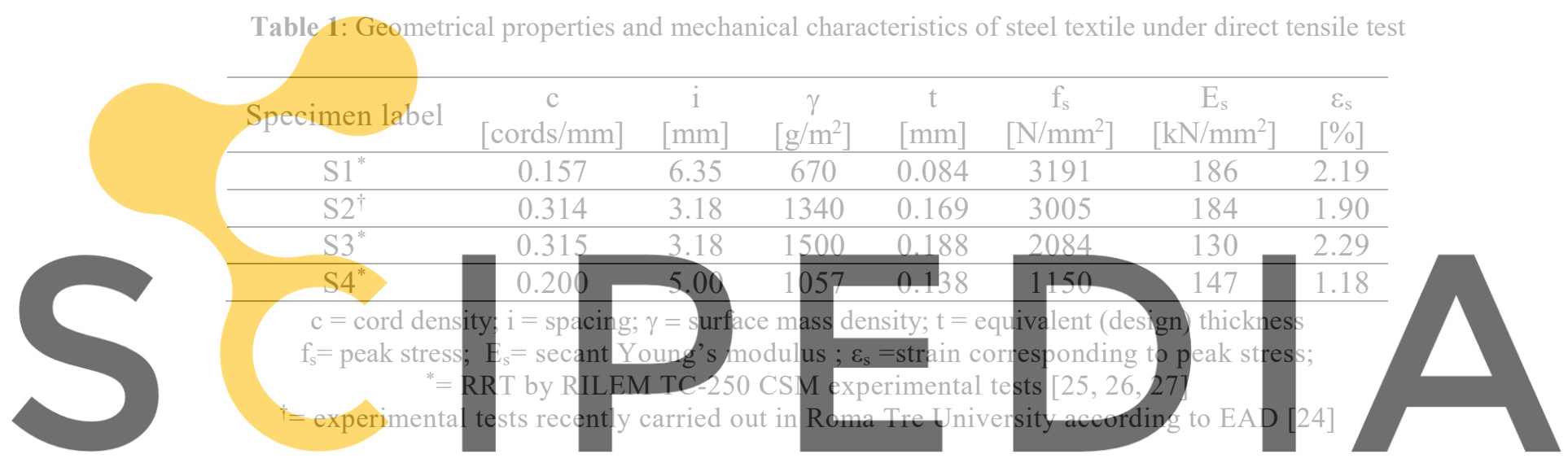

Table 1 reports the main results of direct tensile tests on bare textiles: galvanized steel

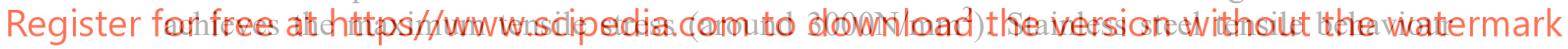
assumes Young's modulus lower than galvanized one, which could depend not only on the steel treatment (galvanized vs stainless) but also on the different cord architecture, causing a limited easy handling as well.

\subsection{Tensile behaviour of SRG coupons}

Direct tensile test provides also the constitutive behaviour of SRG (Figure 1.2). The main mechanical parameters in the un-cracked, cracking, fully cracked stages are collected in this paragraph [22, 23]. In order to make SRG coupons for direct tensile tests, the four abovementioned textiles are combined with the following mortars:

ML) Lime based mortar with geopolymeric binders.

MG) Geopolymeric mortar.

MP) Lime and pozzolana based mortar.

MR) Fibre-reinforced cement mortar with polymeric additives.

Table 2 summarizes and compares the experimental results and failure modes (Figure 2.1), of six SRG systems, from Roma Tre University ${ }^{(\dagger)}[24]$ and Rilem TC 250-CSM ${ }^{(*)}$ experimental investigations [25, 26, 27]. 
Francesca Roscini, Stefano De Santis, Pietro Meriggi and Gianmarco de Felice

Table 2: Properties of mortars and mechanical characteristics of SRG coupons under direct tensile test

\begin{tabular}{|c|c|c|c|c|c|c|c|c|c|}
\hline $\begin{array}{c}\text { Steel } \\
\text { textile }\end{array}$ & \multicolumn{4}{|c|}{ Inorganic mortar } & \multicolumn{5}{|c|}{ SRG direct tensile results } \\
\hline Label & Label & $\begin{array}{c}\mathrm{f}_{\mathrm{cm}} \\
{\left[\mathrm{N} / \mathrm{mm}^{2}\right]}\end{array}$ & $\begin{array}{c}\mathrm{E}_{\mathrm{cm}} \\
{\left[\mathrm{kN} / \mathrm{mm}^{2}\right]}\end{array}$ & $\begin{array}{c}\mathrm{f}_{\mathrm{tm}} \\
{\left[\mathrm{N} / \mathrm{mm}^{2}\right]}\end{array}$ & $\begin{array}{c}\mathrm{f}_{\mathrm{t}} \\
{\left[\mathrm{N} / \mathrm{mm}^{2}\right]}\end{array}$ & $\begin{array}{c}\varepsilon_{\mathrm{t}} \\
{[\%]}\end{array}$ & $\begin{array}{c}\mathrm{E}_{1 \mathrm{~m}} \\
{\left[\mathrm{kN} / \mathrm{mm}^{2}\right]}\end{array}$ & $\begin{array}{c}E_{3 \mathrm{~m}} \\
{\left[\mathrm{kN} / \mathrm{mm}^{2}\right]}\end{array}$ & $\begin{array}{c}\text { Failure } \\
\text { mode }\end{array}$ \\
\hline $\mathrm{S}^{*}{ }^{*}$ & MI & 206 & 1142 & 5.47 & 3461 & 2.03 & 914 & 184 & $\mathrm{~A}-\mathrm{AB}$ \\
\hline $\mathrm{S} 2^{\dagger}$ & $\mathrm{MIL}$ & 20.0 & 11.42 & 5.42 & 2918 & 1.82 & 1063 & 187 & $\mathrm{~A}$ \\
\hline $\mathrm{S}^{*}{ }^{*}$ & & & 2200 & & 3365 & 1.90 & 1718 & 186 & $\mathrm{~A}-\mathrm{AB}$ \\
\hline $\mathrm{S} 2 \dagger$ & $\mathrm{MG}$ & 56.3 & 22.01 & 10.31 & 2964 & 1.92 & 1352 & 195 & $\mathrm{~A}$ \\
\hline $\mathrm{S}^{*}$ & MP & 6.4 & 6.31 & 1.24 & 2448 & 1.75 & 547 & 178 & $\mathrm{~A}-\mathrm{AB}$ \\
\hline $\mathrm{S} 4^{*}$ & MR & 22.7 & 10.0 & 11.2 & 1045 & 1.23 & 892 & 102 & $\mathrm{~B}$ \\
\hline
\end{tabular}

$\mathrm{f}_{\mathrm{cm}}=$ compressive strength; $E_{\mathrm{cm}}=$ Young's modulus from tests on cubic specimens; $\mathrm{f}_{\mathrm{tm}}=$ tensile strength from three-point bending tests; $\mathrm{f}_{\mathrm{t}}=$ peak stress $\varepsilon_{\mathrm{t}}=$ strain corresponding to peak stress; $\mathrm{E}_{1 \mathrm{~m}}=$ Young's modulus in un-cracked stage; $\mathrm{E}_{3 \mathrm{~m}}=$ Young's modulus in cracked stage.

"= RRT by RILEM TC-250 CSM experimental tests $[25,26,27]$ = experimental tests recently carried out in Roma Tre University according to EAD [23, 24]
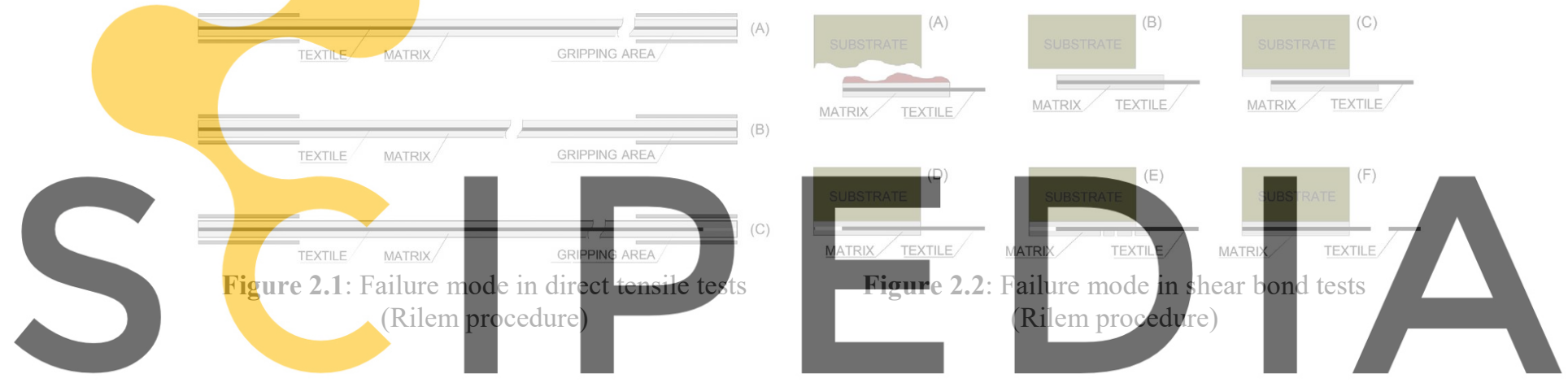

Experimental data collected in Table 2 show that peak stress values $\left(\mathrm{f}_{\mathrm{t}}\right.$ ) and Young's

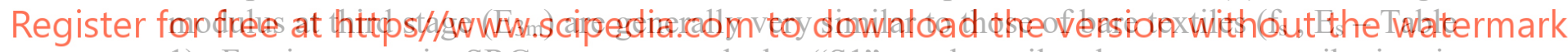
1). For instance, in SRG systems made by "S1" steel textile, the mortar contribution is calculated up to $8 \%$, definitely more than ones made by "S2".

This phenomenon can be attributed to the fact that the low density of cords well-establishes a stress transfer among mortar layers, promoting the mechanical interlocking between cords surface and mortar. At the same time, the maximum contribution of mortar is detected for "S3MP" system, in which the SRG peak stress value increases by $18 \%$ with respect to the dry steel textile. In this case, mortar improves the loading distribution between steel cords. For each test on SRG carried out under direct tensile, the ultimate strain corresponding to peak stress value is very close to that calculated for bare textiles, with the only exception of "S3-MP".

Concerning the failure modes (Figure 2.1), in general the main failures occur near the gripping areas (Failure mode "A") because of local stress concentration, anticipated by a progressive cracking development along the entire length of the coupon. Ruptures took place in the middle (Failure mode "B") of the coupon only for "S4-MR" system. Failure "C", characterized by cracking in the length of the specimen and fibers slippage, in any case is not observed.

From this test type, tension stiffening could be also clearly observed thanks to the distributed crack pattern. For both systems made by "S2" steel textile, crack spacing (Figure 3) is similar and as a result, the failure mode does not depend on the type of the mortar. 

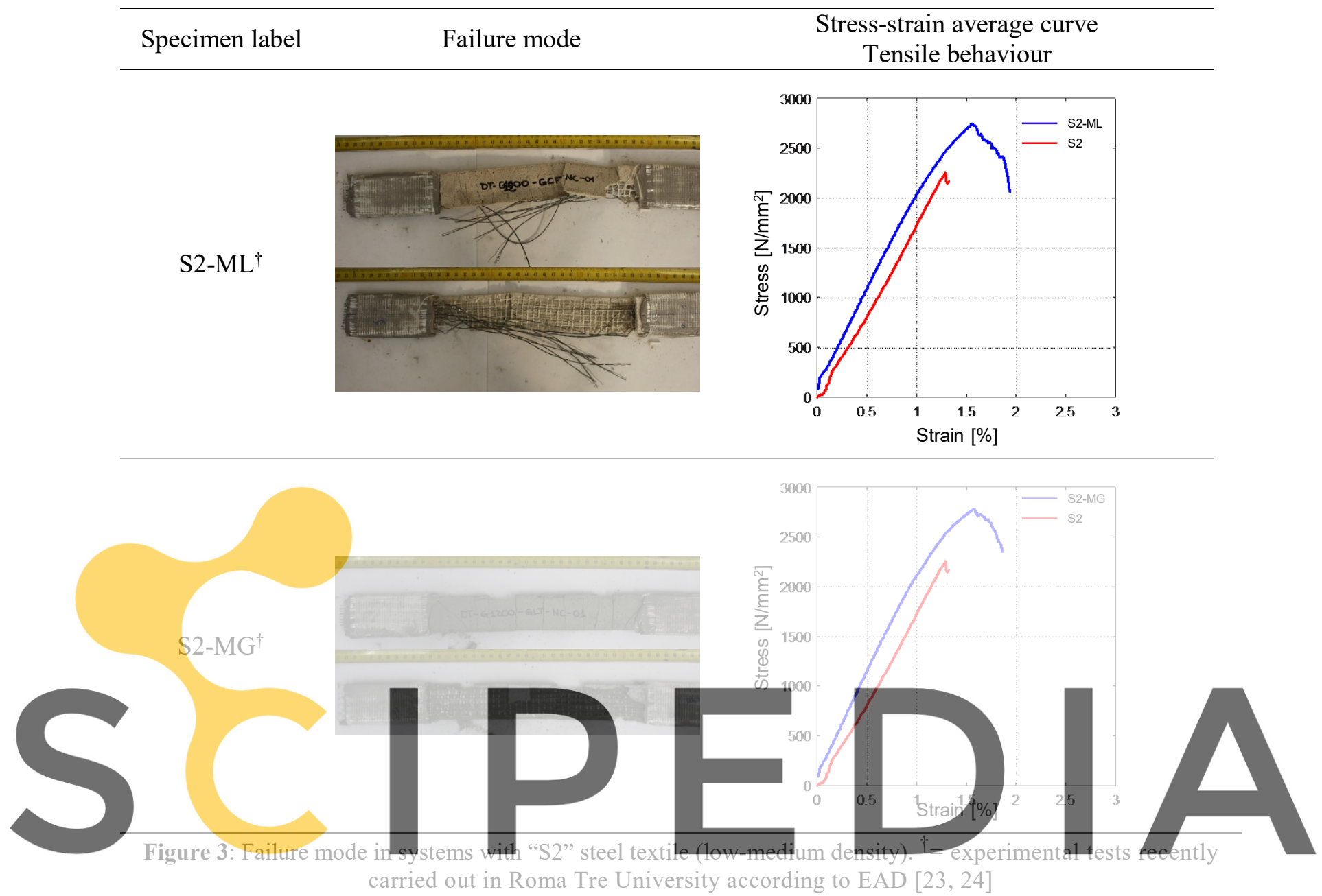

Register for free at https//www.scipedia.com to download the version without the watermark 3 SRG-TO SUBSTRATE BOND BEIHAVIOUR

Single-lap shear bond test (Figure 1.3) allows studying the SRG-to-substrate stress transfer behaviour, which is represented by the following properties: stress at peak load $\left(\mathrm{f}_{\mathrm{b}}\right)$, exploitation ratios $\left(\eta_{d r y}=f_{b} / f_{s}\right.$, the amount of dry textile tensile strength that is exploited at bond failure; $\eta_{\text {comp }}=f_{b} / f_{t}$, the amount of SRG tensile strength that is exploited at bond failure). Failure modes are also recognized (Figure 2.2): failure mode " $\mathrm{A}$ " corresponds to debonding with cohesive failure of the substrate; failure mode " $\mathrm{B}$ " happens when debonding occurs at the matrix-to-substrate interface. For debonding at the textile-to-matrix interface, failure mode is named "C". Failure mode " $\mathrm{D}$ " identifies the textile slippage within the mortar matrix. Failure mode "E" occurs when textile slippage within the matrix and cracking of the outer layer of mortar are observed. Tensile rupture of the textile (out of bonded area) is classified in failure mode " $F$ ". In the following paragraphs shear bond performances of SRG composites bonded to different substrates (concrete, clay brick masonry and tuff blocks) are discussed. The following sections collect the experimental data provided by Ascione and co-authors [30] for concrete substrate, Round Robin Test RILEM TC 250-CSM procedures [25] for brick masonry, and finally others research documents for tuff substrate [31, 32]. 


\subsection{SRG-to-concrete bond behaviour}

The analysis of SRG-to-concrete substrate bond behaviour is illustrated in a recent research available in literature [30], in which different parameters have been investigated. Herein, tests with manufacturing and curing characteristics of SRG similar to Round Robin Test TC 250CSM procedures are selected. Regarding geometrical dimensions of strengthening strip, the bonded interface length is $300 \mathrm{~mm}$, the width dimension is $100 \mathrm{~mm}$ and the number of layer is chosen equal to 1 . The SRG curing is carried out in room temperature for 28 days and then wet clothes are placed on the top of composite surface each day for two weeks. Inorganic mortar assumes these properties: $>50 \mathrm{MPa}$ is the strength in compression, the tensile strength in bending is evaluated $>8 \mathrm{MPa}$ (28days in curing) and the elastic modulus in compression is comprised in a range from 20 to $22 \mathrm{GPa}$. In addition, the properties of concrete prisms are comparable to reinforced concrete in existing buildings (concrete cylindrical strength after 28 days in the range of $13-25 \mathrm{MPa}$ ). The surface finish (bush hammered and sandblasted) and the density of steel reinforcement ("S1" an "S2") are the only variable parameters.

Table 3: Shear bond tests results for SRG-to-concrete substrate

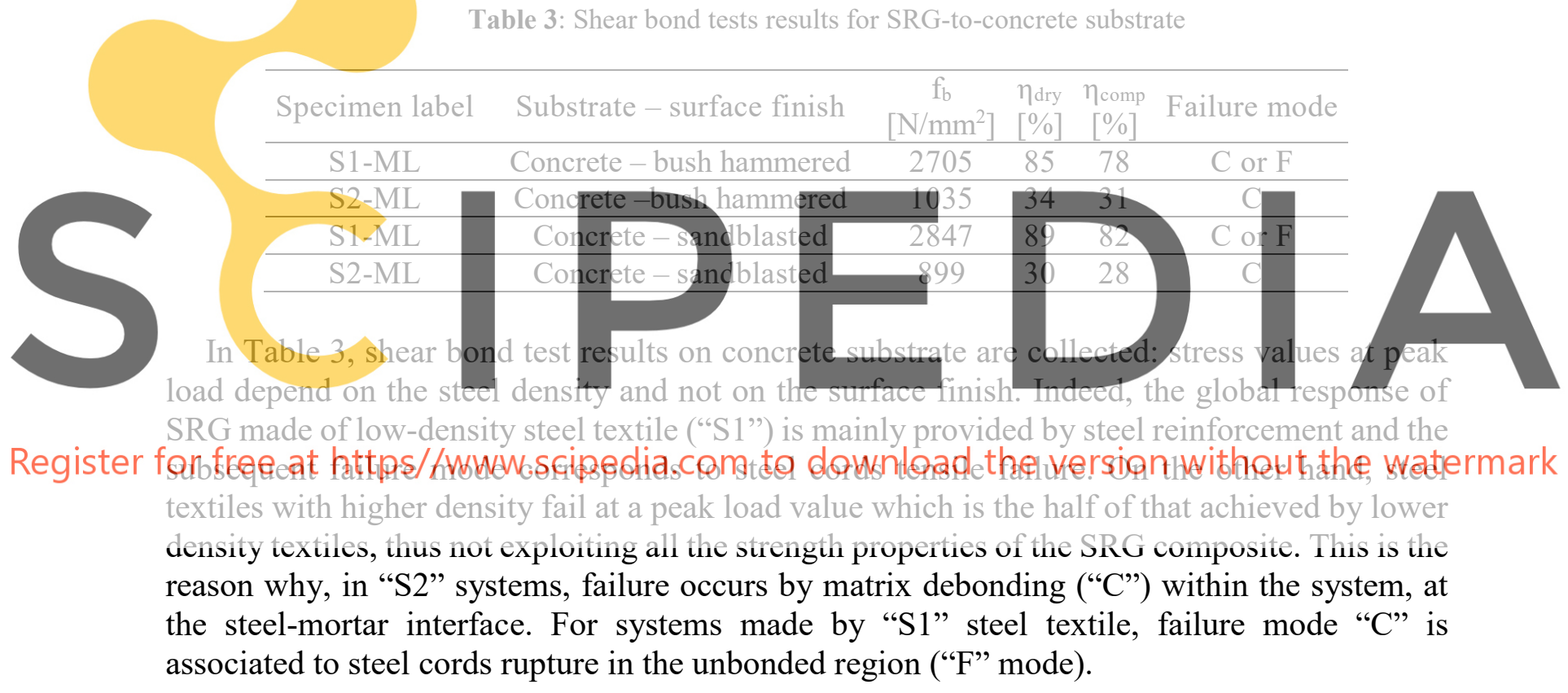

\subsection{SRG-to-masonry bond behaviour}

Steel Reinforced Grout-to-masonry substrate bond behaviour was deeply studied in the Round Robin Test initiative organized by the Rilem TC 250-CSM, with laboratories of several research centres from all Europe involved [25].

The maximum value of stress at peak load was recorded for SRG strengthening made by "S1" galvanized steel and lime mortar (Table 4). Failure occurred in the unbonded textile ("F" mode), therefore both exploitation ratios are very close to $100 \%$. S4-MR system also exhibited a good bond performance, as shown by the high values of the exploitation ratio. In this case, textile slippage within the matrix took place (Failure mode "D"). 
Table 4: Shear bond tests results for SRG-to-masonry substrate

\begin{tabular}{cccccc}
\hline \multirow{2}{*}{ Specimen label } & \multirow{2}{*}{ Substrate } & $\mathrm{f}_{\mathrm{b}}$ & \multicolumn{1}{c}{$\eta_{\text {dry }}$} & $\eta_{\text {comp }}$ & Failure mode \\
& {$\left[\mathrm{N} / \mathrm{mm}^{2}\right]$} & {$[\%]$} & {$[\%]$} & \\
\hline S1-ML* & Clay brick masonry & 3023 & 95 & 87 & $\mathrm{~F}$ \\
\hline S1-MG* & Clay brick masonry & 2457 & 77 & 71 & $\mathrm{~B}$ or C \\
\hline S3-MP* & Clay brick masonry & 1169 & 56 & 48 & $\mathrm{D}$ \\
\hline S4-MR* & Clay brick masonry & 939 & 82 & 89 & $\mathrm{D}$ \\
\hline
\end{tabular}

\subsection{SRG-to-tuff bond behaviour}

In order to investigate the SRG-to-tuff bond behaviour, test data from De Santis and de Felice [31] and Bilotta and co-autohors [32] are analysed in this paragraph. From the first document published in 2015, shear bond test performances regarding tuff unit strengthened with two systems ("S1-ML" and "S1-MG") are reported in this study. At the same time, other two cases are provided by the second research: in particular, two typologies of SRG systems applied to tuff units are analysed. Both the systems are made of the same mortar, named "MH", which is a bi-component premixed pozzolan-based grout also including hydraulic natural lime, sand, polymeric additives and short glass fibers spread in the matrix, having $12.4 \mathrm{~N} / \mathrm{mm}^{2}$ compressive strength and $6.2 \mathrm{~N} / \mathrm{mm}^{2}$ flexural strength. Two galvanized steels are used: three specimens are manufactured with "S5" steel textile and other three with "S6" steel type. Their properties are

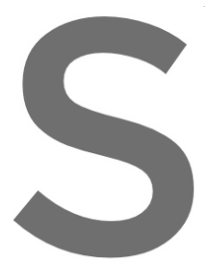
reported in Table 5
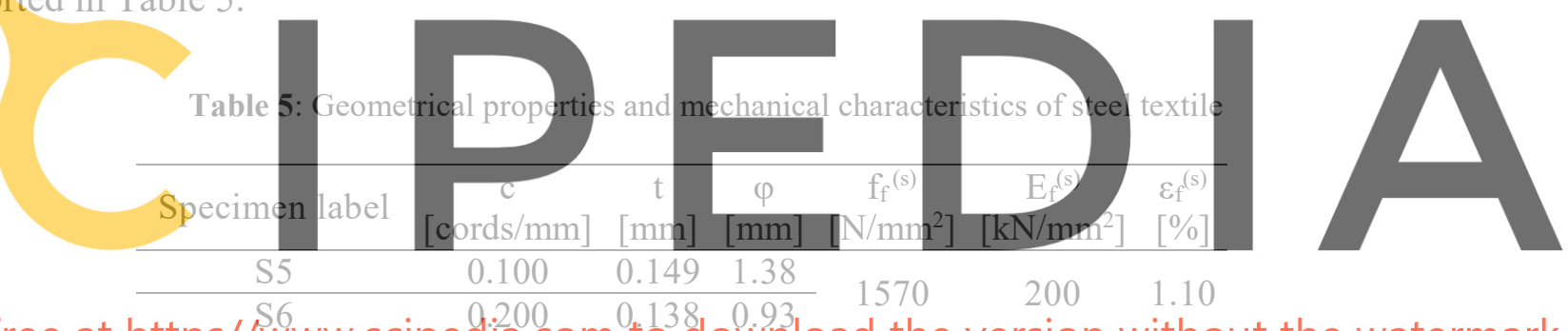

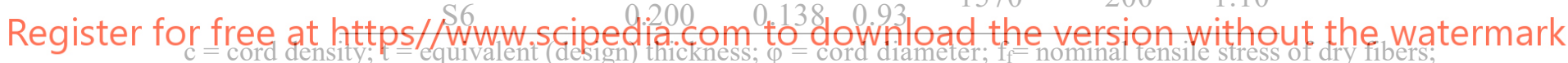
$\mathrm{E}_{\mathrm{f}}=$ Young's modulus ; $\varepsilon_{\mathrm{f}}=$ ultimate strain; ${ }^{(\mathrm{s})}=$ data provided by supplier

Table 6: Shear bond tests results for SRG-to-tuff substrate

\begin{tabular}{cccccc}
\hline Specimen label & Substrate & $\begin{array}{c}\mathrm{f}_{\mathrm{b}} \\
{\left[\mathrm{N} / \mathrm{mm}^{2}\right]}\end{array}$ & $\begin{array}{c}\eta_{\text {dry }} \\
{[\%]}\end{array}$ & $\begin{array}{c}\eta_{\text {comp }} \\
{[\%]}\end{array}$ & Failure mode \\
\hline S1-ML & Single tuff block & 1676 & 52.6 & & $\mathrm{C}$ \\
\hline S1-MG & Single tuff block & 1876 & 58.9 & - & A-C \\
\hline S5-MH-1 & Single tuff block & 183 & 12 & - & B \\
\hline S5-MH-2 & Single tuff block & 414 & 28 & - & D \\
\hline S5-MH-3 & Single tuff block & 414 & 24 & - & D \\
\hline S6-MH-1 & Single tuff block & 1118 & 71 & 110 & F \\
\hline S6-MH-2 & Single tuff block & 1159 & 74 & 114 & F \\
\hline S6-MH-3 & Single tuff block & 476 & 30 & 47 & B \\
\hline S6-MH-4 & Single tuff block & 421 & 27 & 41 & B \\
\hline
\end{tabular}

From Table 6, experimental data show the high variability of single-lap shear bond tests 
carried out on tuff substrate. SRG systems made by "S1" galvanized steel textile achieve the maximum bond value: in particular, "S1-MG" exhibited a higher value of the bond strength with respect to "S1-ML", because geopolymer mortar is stronger than lime one. On the other hand, the maximum exploitation was achieved only for two tests $\left(\eta_{\text {dry }}=71-74 \% \eta_{\text {comp }}=110\right.$ $114 \%$ ). Generally, in the other tests, a relatively lower bond capacity was observed, because of the weakness of the substrate and inappropriate surface preparation (debonding at tuffmatrix interface, failure mode "B").

\section{CONCLUSIONS}

The critical review of existing experimental evidences leads to the following observations on the tensile and bond behaviour of SRG composites:

- $\quad$ The rough surface of the steel cords provides an effective load transfer capacity with the mortar, as demonstrated by the distributed cracks developing under tensile loading; on the basis of available results, this is independent from the type of mortar matrix; The good interaction between steel cords and mortar matrix contributes to the efficiency of the SRG-to-substrate shear transfer capacity, as demonstrated by the high values of the exploitation ratios (about $\eta=80 \%$ ) detected in shear bond tests, with failure occurring by either detachment at the textile-to-matrix interface or tensile rupture of the cords.

On the other hand, the smoother surface of steel ropes may lead to the slippage of the

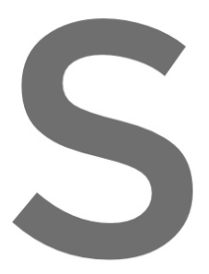
textile associat The developine relies on the

The following issues influence on influence on substrate-to-SRG bond bein apacity (about $\eta=50 \%$ ),
cking between textile and mortar
cords.
search efforts:
pacity of diameter and surface of steetrion, matrix highly irregular masonry surfaces and on weak substrate materials;

Acknowledgements. This work was carried out within the Research Project "SICURA Sustainable technologies for the seismic protection of the cultural heritage" (2018-2020) funded by Lazio Region. Funding is also acknowledged from the Italian Ministry of Education, University and Research (MIUR), attributed to the Department of Engineering of Roma Tre University, in the frame of the Departments of Excellence Initiative (2018-2022).

\section{REFERENCES}

[1] Wobbe, E. Silva, P. Barton, B.L. Dharani, L.R. Birman, V. Nanni, A. Alkhrdaji, T. Thomas, J. and Tunis, G. Flexural capacity of RC beams externally bonded with SRP and SRG. In: International SAMPE Technical Conference, (2004), pp. 3009-3016.

[2] Grande, E. Imbimbo, M. and Sacco, E. Modeling and numerical analysis of the bond behavior of masonry elements strengthened with SRP/SRG. Composites Part B: Engineering (2013) 55: 128 138.

[3] De Santis, S. Napoli, A. de Felice, G. and Realfonzo, R. Strengthening of structures with Steel Reinforced Polymers: A state-of-the-art review. Composites Part B: Engineering (2016) 104: 87- 
110.

[4] Razavizadeh, A. Ghiassi, B. and Oliveira, D.V. Bond behavior of SRG-strengthened masonry units: Testing and numerical modeling. Construction and Building Materials (2014) 64: 387-397.

[5] De Santis, S. and De Felice, G. Tensile behaviour of mortar-based composites for externally bonded reinforcement systems. Composites Part B: Engineering (2015) 68: 401-413.

[6] De Santis, S. Bond behaviour of Steel Reinforced Grout for the extrados strengthening of masonry vaults. Construction and Building Materials (2017) 150:367-382.

[7] Malena, M. Closed-form solution to the debonding of mortar based composites on curved substrates. Composites Part B: Engineering (2018) Volume 139: 249-258.

[8] Borri, A. Castori, G. and Corradi, M. Shear behavior of masonry panels strengthened by high strength steel cords. Construction and Building Materials (2011) 25: 494-503.

[9] Thermou, G.E. De Felice, G. De Santis, S. Alotaibi, S. Roscini, F. Hajirasouliha, I. Guadagnini, M. Mechanical characterization of multi-ply steel reinforced grout composites for the strengthening of concrete structures. 9th International Conference on Fibre-Reinforced Polymer (FRP) Composites in Civil Engineering. (CICE 2018) pn. 298-305.

[10] Thermou, G.E. De Santis, S. de Felice, G. Alotaibi, S. Roscini, F. Hajirasouliha, I. Guadagnini M. Bond behavior of Multi-Ply Steel Reinforced Grout Composites. Construction \& Building Materials. (To appear)

[11] Huang, X. Birman, V. Nanni, A. and Tunis, G. Properties and potential for application of steel reinforced polymer and steel reinforced grout composites. Composites Part B: Engineering (2005) 36: 73-82.

[12] Da Porto, F. Stivanin, E. Gabim, E. Valluzzi, M.R. SRG applications for structural strengthening of $\mathrm{R}$ beams. $A C I$ Spec

13] Napoli, A., Realifon Experimental invest

[14] Thermou, G.E. and H reinforced grout jackets. Composites Part B:

[15] De Santis, S. Roscin ec Pub (2012); 286: 119-1
zo, R. Reinforced condrotion.
gation. (2015) Construction
Hajirasouliha, I. Compressi
kets. Composites Part B:
i, F. and de Felice, G. F
out. Composites Part B:
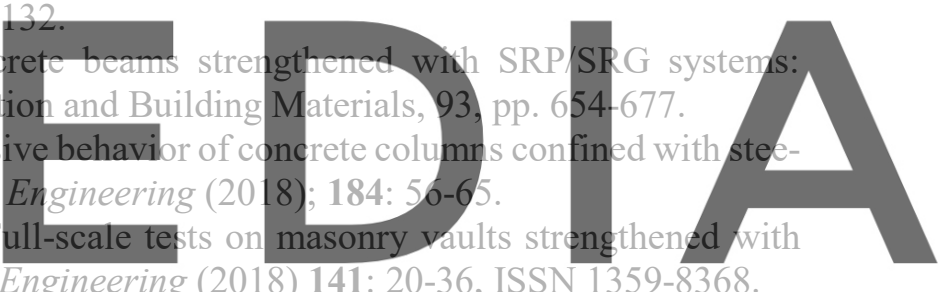
Steel Reinforced Grout. Composites Part B: Engineering (2018) 141: 20-36, ISSN 1359-8368.

[16] De Santis, S. De Canio, G. de Felice, G. Meriggi, P. Roselli, I. Out-of-plane seismic retrofitting

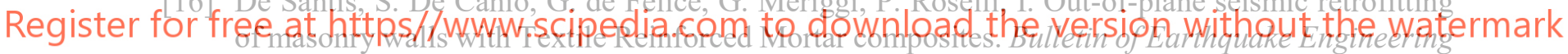
(2019) 17(11):6265-6300.

[17] de Felice, G. De Santis, S. Realfonzo, R.Napoli, A. Ascione, F. Stievanin, E. Cescatti, E. Valluzzi, M.R. Carloni, C. and Camata, G. State of the art of steel reinforced grout applications to strengthen masonry structures. American Concrete Institute, ACI Special Publication (2018) June, Issue SP 326.

[18] Carloni, C., Ascione, F., Camata, G., De Felice, G., De Santis, S., Lamberti, M., Napoli, A., Realfonzo, R., Santandrea, M., Stievanin, E., Cescatti, E., Valluzzi, M.R. An overview of the design approach to strengthen existing reinforced concrete structures with SRG

(2018) American Concrete Institute, ACI Special Publication, 2018-June (SP 326).

[19] de Felice, G. Aiello, M.A. Caggegi, C. Ceroni, F. De Santis, S. Garbin, E. Gattesco, N. Hojdys, Ł. Krajewski, P. Kwiecień, A. Leone, M. Lignola, G.P. Mazzotti, C. Oliveira, D.V. Papanicolaou, C. Poggi, C. Triantafillou, T. Valluzzi, M.R. Viskovic, A. Recommendation of RILEM TC 250CSM: Test method for Textile Reinforced Mortar to substrate bond characterization. Materials and Structures (2018) 51(4):95.

[20] ICC-ES (International Code Council - Evaluation Service). (2013). AC434 Acceptance criteria for masonry and concrete strengthening using fiber-reinforced cementitious matrix (FRCM) composite systems. Whittier, CA, US.

[21] CNR (Italian National Research Council). (2019). CNR-DT 215/2018. Istruzioni per la 
Progettazione, l'Esecuzione ed il Controllo di Interventi di Consolidamento Statico mediante l'utilizzo di Compositi Fibrorinforzati a Matrice Inorganica. (In Italian).

[22] ACI-RILEM (ACI 549 0L - RILEM TC 250-CSM Liason Committee). (2019). Guide to Design and Construction of Externally Bonded Fabric-Reinforced Cementitious Matrix (FRCM) and Steel-Reinforced Grout (SRG) Systems for Repair and Strengthening Masonry Structures (to appear).

[23] EOTA (European Organization for Technical Assessment). EAD340275-00-0104 Externallybonded composite systems with inorganic matrix for strengthening of concrete and masonry structures. (to appear)

[24] Roscini, F. Malena, M. and de Felice, G. Experimental evidences and numerical modelling of SRG systems under uniaxial load. 10th International Conference on FRP Composites in Civil Engineering (CICE 2020), Istanbul 1-3 July 2020

[25] De Santis, S. Ceroni, F. de Felice, G. Fagone, M. Ghiassi, B. Kwiecień, A. Lignola, G.P. Morganti, M. Santandrea, M. Valluzzi, M.R. Viskovic, A. Round Robin Test on tensile and bond behaviour of Steel Reinforced Grout systems. Composites Part B: Engineering (2017) 127:100-120

[26] De Santis, S. Hadad, H.A. De Caso y Basalo, F.J. de Felice, G. Nanni, A. Acceptance Criteria for Tensile Characterization of Fabric Reinforced Cementitious Matrix (FRCM) Systems for Concrete and Masonry Repair. Journal of Composites for Construction (2018) 22(6):04018048.

[27] de Felice, T. D'Antino, A. De Santis, S. Meriggi, P. Roscini, F. Lessons learned on the tensile and bond behaviour of Fabric Reinforced Cementitious Matrix (FRCM) composites. Frontiers in Built Environment, section Earthquake Engineering.

[28] Arboleda, D., Carozzi, F.G. Nanni, A. Poggi, C. Testing Procedures for the Uniaxial Tensile

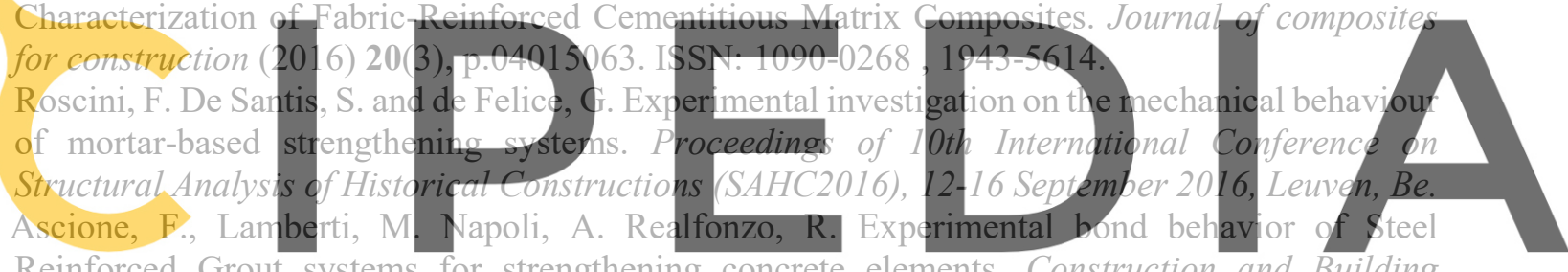

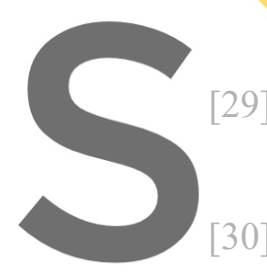
Reinforced Grout systems for strengthening concrete elements. Construction and Building Materials (2020) 2321171.05 .

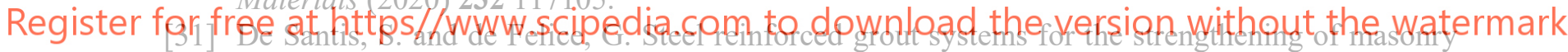
structures. Composite Structures (2015) 134:533-548.

[32] Bilotta, A. Ceroni, F. Nigro, E. Pecce, M. Experimental tests on FRCM strengthening systems for tuff masonry elements. Construction and Building Materials (2017) 138: 114-133.

[33] Cancelli, A.N. Aiello, M.A. Casadei, P. Experimental investigation on bond properties of SRP/SRG - Masonry systems. Proc. 8th Int. Symp. on FRPRCS-8 University of Patras, Patras, Greece, July 16-18 (2007).

[34] De Santis, S. Stryszewska, T. Bandini, S. de Felice, G. Hojdys, Ł. Krajewski, P. Kwiecień, A. Roscini, F. Zając, B. Durability of Steel Reinforced Polyurethane-to-substrate bond. Composites Part B: Engineering (2018) 153:194-204.

[35] De Santis, S. Meriggi, P. de Felice, G. Durability of Steel Reinforced Grout composites. 17th International Brick and Block Masonry Conference (IB2MaC 2020)

[36] Meriggi, P., de Felice, G., De Santis, S., Morganti, M., Roscini F. Durability of Steel Reinforced Grout systems subjected to freezing-and-thawing conditioning. 1st fib Italy YMG Symposium, 15 October 2019, Parma, Italy. 